\title{
Environmental justice for the governance of aquatic environments
}

\author{
Paloniemi, Riikka
}

2018-01-08

Paloniemi , R, Niemelä , J , Soininen , N , Laatikainen , T, Vierikko , K, Rekola , A , Viinikka , A, Yli-Pelkonen, V , Assmuth , T , Kopperoinen , L, Peltonen , L , Kuokkanen , T \& Kyttä , M 2018 , 'Environmental justice for the governance of aquatic environments ' , Local Environment, vol. 23 , no. 3 , pp. 366-377 . https://doi.org/10.1080/13549839.2017.1422118

http://hdl.handle.net/10138/307171

https://doi.org/10.1080/13549839.2017.1422118

acceptedVersion

Downloaded from Helda, University of Helsinki institutional repository.

This is an electronic reprint of the original article.

This reprint may differ from the original in pagination and typographic detail.

Please cite the original version. 


\title{
Environmental justice for the governance of aquatic environments
}

\author{
Riikka Paloniemi $^{1 *}$, Jari Niemelä ${ }^{2}$, Niko Soininen ${ }^{3}$, Tiina Laatikainen ${ }^{4}$, Kati Vierikko ${ }^{2}$, Aino \\ Rekola $^{1}$, Arto Viinikka ${ }^{1}$, Vesa Yli-Pelkonen ${ }^{2}$, Timo Assmuth ${ }^{1}$, Leena Kopperoinen ${ }^{1}$, Lasse \\ Peltonen $^{1}$, Tuomas Kuokkanen ${ }^{3}$, Marketta Kyttä ${ }^{4}$
${ }^{1}$ Environmental Policy Center, Finnish Environment Institute (SYKE), Helsinki, Finland
${ }^{2}$ Department of Environmental Sciences, University of Helsinki, Helsinki, Finland
${ }^{3}$ Law School, University of Eastern Finland (UEF), Joensuu, Finland
${ }^{4}$ Aalto University, Helsinki, Finland

\section{Accepted final draft version}

Reference:

Paloniemi, R., Niemelä, J., Soininen, N., Laatikainen, T., Vierikko, K., Rekola, A., Viinikka, A., Yli-Pelkonen, V., Assmuth, T., Kopperoinen, L., Peltonen, L., Kuokkanen, T., Kyttä, M. (2018) Environmental justice for the governance of aquatic environments. Local Environment 23: 366-377.

http://doi.org/10.1080/13549839.2017.1422118

\section{Disclaimer:}

The PDF document is a copy of the final version of this manuscript that was subsequently accepted by the journal for publication. The paper has been through peer review, but it has not been subject to any additional copy editing or journal-specific formatting. It thus looks different from the final published version, which may be accessed following the DOI above.

\footnotetext{
*Corresponding author. Email: riikka.paloniemi@ymparisto.fi
} 


\begin{abstract}
Environmental justice sheds light on the distributive and procedural aspects of planning and decision making. We examined the challenges arising from the perspective of environmental justice on multi-level and participatory environmental governance by exploring the governance of aquatic environments in the Helsinki Metropolitan Area. We found three main challenges and potential responses to them. First, even though most of Helsinki's shoreline is free and/or accessible by road and accordingly used actively by people for recreational purposes, many parts of the shoreline are perceived as inaccessible, reflecting a need to combine factual and perceived accessibility of aquatic environments in detail during the planning processes and to discuss reasons for possible discrepancies between these two. Second, there was a remarkable seasonal variation in the use of aquatic environments, so more attention should be paid to social-demographic factors explaining the distribution of the use of urban nature. Third, it seems to be difficult to capture the variety of perceptions of people and to integrate them into planning and decision-making processes even on a local scale, and this challenge is likely even more pronounced on higher levels of planning and governance. Thus, better integration of regional and local-scale planning procedures should be encouraged. Building on these observations, we conclude that integration of procedural and distributive environmental justice into the practices of the governance of aquatic environments could remarkably decrease unwanted trade-offs and potential conflicts in their use and management.
\end{abstract}

\title{
Keywords:
}

aquatic environments, environmental governance, distributive justice, procedural justice, recreation 


\section{Introduction}

Having its background in the rise of social movements looking for just distribution of environmental burdens and benefits in the early 1980s, one major element in environmental justice is inequitable distribution of environmental or health benefits and hazards among ethnic minorities or low-income residents (Davos1986, Hester 1987. Agyeman et al. 2003, Agyeman 2005). However, environmental justice is not only about distribution of benefits and risks. Another important aspect is procedural justice, interlinked and interrelated with distributive one. Procedural justice refers to means, methods and approaches used in public participation in policy and decision making processes, to recognition of various individuals and social groups, including the disadvantaged and vulnerable ones, as potential stakeholders in such processes, as well as to their capacities to participate (Schlosberg 2007, Boone et al. 2009, Paloniemi et al. 2015). Finally, the essential difference between environmental and more general social justice, is the former's focus on environment, including species and ecosystems as a matter of distribution or even as stakeholders (Schlosberg 2007).

Taking into consideration the dependence of humans on ecosystems and their functions, over the years, the agenda of environmental justice research has expanded from a focus on environmental harm to cover environmental amenities and benefits, essential for health and well-being. In the urban contexts, to which we focus on in this paper, these include the use of and access to urban green and blue spaces, including parks, shorelines and other environmental elements as well as the well-being and social benefits provided by them (e.g. Tzoulas and Greening 2011, Völker \& Kinstemann 2011, Pietilä et al. 2015). Finally, given that such benefits for residents are mainly derived by urban nature when it is used, the questions on equal opportunities, fairness and justice become unavoidable. The participation in the democratic process by various stakeholder groups can help to achieve relevant-and often contested - contextual experience-based knowledge, values and perspectives that are important in urban planning (Giller et al. 2008).

The ecosystem service concept integrates the benefits that humans derive from nature to policies aiming at maintaining such services. The role of Millennium Ecosystem Assessment (2005) has been essential in the operationalization of the provisioning, regulating, cultural and supporting services onto policy arenas. Even though recently, environmental justice aspects have been linked to ecosystem services (Ernstson 2013, Sikor 
2013), provision of various ecosystem services are yet to be comprehensively examined under the notion of justice (Kabisch and Haase 2014).

Although environmental justice has been recognized as an important goal in urban planning, it remains poorly studied in many European countries, including the Nordic welfare states with comprehensive planning regimes and assumptions of equity in terms of environmental rights and amenities. However, environmental justice issues can also be identified in egalitarian countries, even if they have only seldom been articulated as such (Laakkonen 2001, Laine and Peltonen 2003, Chaix et al. 2006). Intensifying urbanization is resulting in a need to pay much more attention to just local distribution of ecosystem services and to capacities and abilities of various stakeholders to use them, as well as to the ways the planning and decisions related to them are facilitated and made.

By focusing on the governance of aquatic environments in this paper, we shed light on the capacities of and the need to improve the multi-level and multi-actor governance of aquatic environments from the perspective of environmental justice by focusing on the Helsinki Metropolitan Area (HMA) (Figure 1). This area, including the cities of Helsinki, Vantaa, Espoo and Kauniainen, is constantly growing in population, and much of the recent development in the HMA has been planned and implemented in coastal locations. Given that there are increasing socio-economic segregation within the area (Vilkama 2011, Vaattovaara and Kortteinen 2012), cumulating environmental pressures and alterations of recreational needs due to demographic changes and diversification of population groups, the area interestingly demonstrates the needs and suggests opportunities to improve both distributive and procedural aspects in environmental governance.

This paper is based on research collaboration of the ENJUSTESS consortium, which consists of the Finnish Environment Institute (SYKE), the University of Helsinki, Aalto University and the University of Eastern Finland. The objective of this consortium was to explore interconnections between environmental justice and ecosystem services with a novel focus on urban aquatic environments. This research project specifically examined how environmental justice was realized in the distribution, use and management of aquatic environments in the HMA. In this paper we conclude our research findings that were obtained using doctrinal and regulatory analysis of existing legal instruments regulating aquatic environments and their ecosystem services, place-based mapping method, case study on storm water governance and interviews of planners and authorities governing aquatic environments in the HMA. 


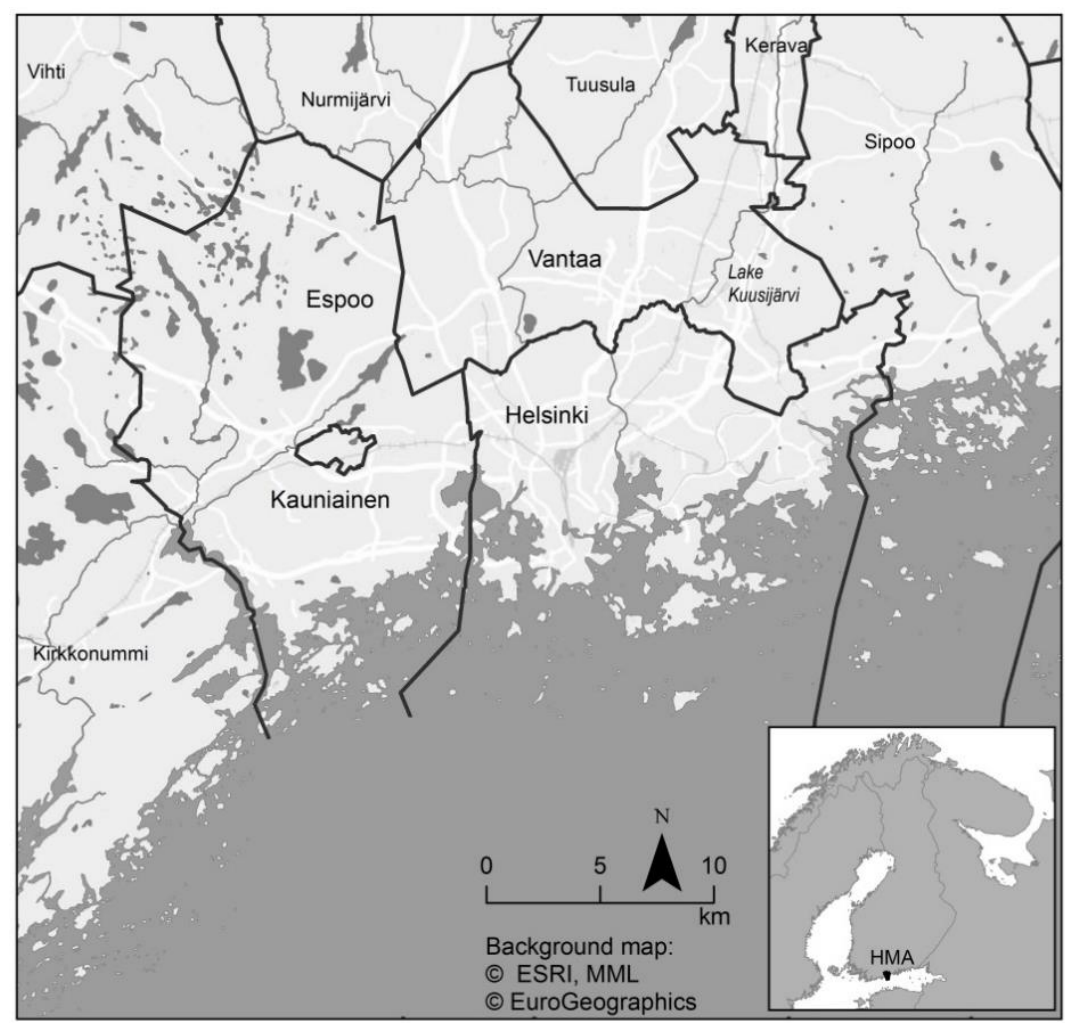

Figure 1. The HMA consisting of the cities of Helsinki, Espoo, Vantaa and Kauniainen. In this paper, we focus on the environmental justice of aquatic environments in the HMA.

We explore the interlinkages of environmental justice and ecosystem services by analysing the distribution of aquatic environments and accessibility options for people to benefit from them, as well as the promotion of procedural justice in related planning processes. We begin by describing key governance instruments related to distribution of aquatic environments and their ecosystem services that operate on various spatial scales (see Söderberg 2016). We then demonstrate how distributive and procedural justice works on the local level and what kind of justice-related challenges exist in practice by focusing on recreational services. Finally, we conclude by discussing the implications of recognized local-level challenges to the multi-level governance of aquatic environments.

\section{Multi-level and multi-actor governance of aquatic environments}

In Finland, the distribution of aquatic ecosystem services is mainly governed by four separate but interlinked planning instruments. The instruments are: (1) river basin management plans (RBMPs), (2) marine plans (MPs), (3) land-use plans (LUPs) and (4) maritime spatial plans (MSPs) (Figure 2). The level of detail, the normative basis and the 
operationalization stage of these instruments varies, generally being most firmly established by the law for LUPs, which consist of several hierarchical levels of planning in dedicated organizations and processes.

Geographically, RBMPs cover freshwaters, and immediate coastal waters up to 1 nautical mile from the baseline; MPs cover the coastal and marine waters (internal waters, the territorial sea and the exclusive economic zone); LUPs cover freshwaters, coastal waters and the territorial sea in addition to land areas; and MSPs cover marine waters outside the coast. Additionally, there are several related planning instruments that contain spatial elements, such as local and regional water supply and fisheries plans.

The four planning instruments are here distinguished along three principal dimensions: (1) whether they focus on safeguarding and improving the ecological condition of aquatic environments (RBMPs and MPs) or mainly facilitate and regulate social and economic development (LUPs and MSPs); (2) whether they make use of spatial planning (LUPs and MSPs) or stick to other planning instruments (RBMPs and MPs); and (3) whether they primarily address aquatic areas (RBMPs, MPs, MSPs) or also other areas (LUPs) (i.e. how they fit a broad inter-sector governance framework). Moreover, especially with regard to procedural environmental justice, all these instruments vary in terms of how they include public participation and bottom-up influence alongside a top-down governance approach.

Aside from LUPs, in which the European Union (EU) lacks legal competence to pass legislation due to the inherently strong national and local mandate, the other three planning instruments are strongly influenced by EU secondary legislation. RBMPs and MPs focus on achieving a good environmental status of freshwaters and marine waters and/or avoiding their further deterioration, as stipulated in Article 4 of the Water Framework Directive (WFD, 2000/60/EC) and Article 1 of the Marine Strategy Framework Directive (MSFD, 2008/56/EC). Both directives are transposed into Finnish legislation by the Act on the Organisation of River Basin Management and the Marine Strategy (1299/2004). In order to achieve the ecological objectives of the WFD and the Act, the regional Finnish Centres for Economic Development, Transport and the Environment are tasked with preparing RBMPs and programmes of measures at a river basin level. With regard to marine waters and the implementation of the MSFD, the Finnish Ministry of the Environment is tasked with producing MPs and programmes of measures. In contrast to RBMPs, this is done at the national, rather than regional, level. 


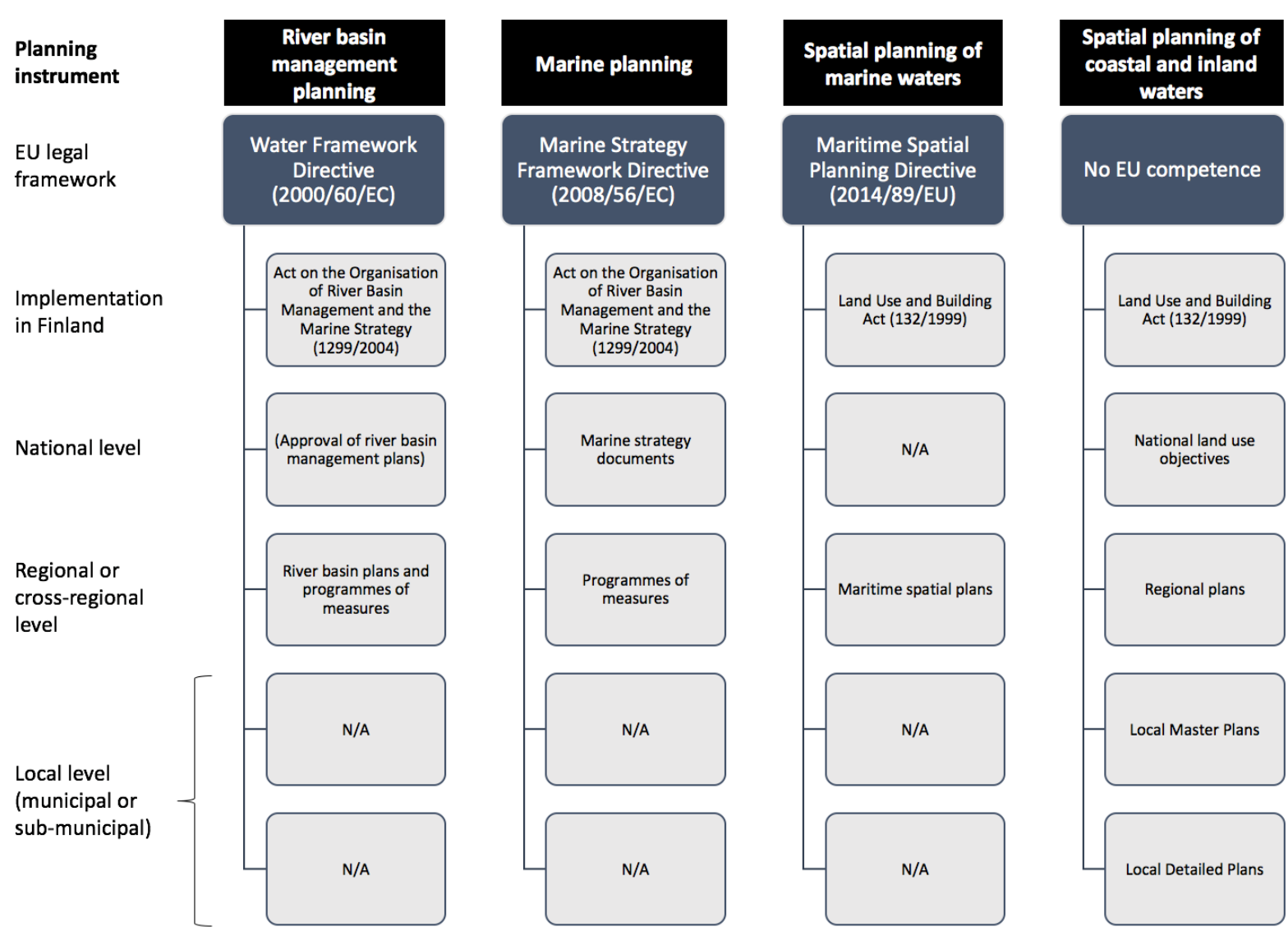

Figure 2. Multi-level governance of aquatic environments at the EU level and in Finland.

N/A means not available.

Spatial planning systems can be similarly divided between freshwaters and marine areas. In Finland, the land-use planning system provided by the Land Use and Building Act (132/1999) extends to the spatial planning of freshwaters and the coast. The act sets a top-down, four-level planning system ranging from national land-use objectives and regional land-use planning to local master plans and detailed plans at the municipal level. While local LUPs are limited by geographical scope to freshwaters and the immediate coast, the authority to conclude regional plans extends to the end of the territorial sea. Beyond the territorial sea, the EU has legislative competence over spatial planning, and under the maritime spatial planning directive (2014/89/EU), EU member states have an obligation to produce MSPs by March 2021. The explicit aim of the directive is to facilitate blue growth in maritime sectors while simultaneously supporting the achievement of good ecological status of the marine environment (COM (2006) 275, final; COM (2007) 575, final; Soininen 2015). The directive is transposed into the Finnish legislation by an amendment to the Land Use and Building Act, which gives the Regional Councils the competence to set up MSPs. 
Of the four planning instruments, an LUP is the only instrument that systematically descends to the local level. This means that most issues concerning the distribution of aquatic ecosystem services are dealt with on the regional or national, rather than local, level. On the other hand, LUPs are normatively strong and well-established in comparison to the instruments based on EU legislation, the implementation and effects of which on the local level still largely remain to be seen, at least for the MPs and MSPs. Furthermore, the four planning instruments (1) have several planning intervals, (2) have various authorities concluding plans and (3) vary in the legal effect they can have on the distribution of aquatic ecosystem services. Consequently, it can be challenging for the end users of aquatic environments to know which planning processes to participate in and when. The local-level instruments (LUP) include participatory processes and negotiation and conflict resolution procedures to a higher degree than the others, but even in this case effective participation requires expertise (Staffans 2004) as well as accepted and justifiable decision processes. Furthermore, the majority of planning decisions having a direct effect on the distributive justice of ecosystem services - such as access to shoreline - are dealt within LUPs, which tend to favour economic development over social values, such as recreation (Granit et al. 2014). Therefore, despite the local-level participatory processes embedded in an LUP, it often fails to achieve and even to properly consider the purported goal of environmental justice.

\section{Distribution of aquatic environments and their accessibility in the} HMA

In this study, we define aquatic environments as all surface water bodies and their immediate shore areas. In the HMA, such areas include the Baltic Sea (the Gulf of Finland), lakes, fluvial environments (especially River Vantaa), small urban surface waters (e.g. streams and ponds) and wetlands. There is a wealth of various aquatic environments in the HMA, but they are unevenly distributed. Especially in the city of Vantaa, there are only a few natural water bodies and no coastlines. However, River Vantaa and its tributaries offer a long shoreline meandering through the city. In addition, there are semi-natural water bodies formed in former gravel pits, and they have been included in the blue infrastructure. The city of Espoo has a long coastline as well as numerous lakes in its northern parts. In Helsinki, the coastline is the most prominent part of the blue infrastructure, but the distribution of water 
bodies is uneven, and especially on the coast, the access to the shoreline is restricted in many places.

Table 1. Estimated free shoreline in the city of Helsinki. Free shore is referring to publicly accessible aquatic environments. The shoreline profile was investigated in terms of free accessibility by using a GIS-based approach with various spatially explicit data. Shoreline 10 operating on scales: 1:5000 - 1:10,000 (Finnish Environment Institute 2016).

\begin{tabular}{lccc}
\hline Type of aquatic environment & $\begin{array}{c}\text { Length of } \\
\text { shoreline }\end{array}$ & Free shoreline & $\begin{array}{c}\text { Percentage of free } \\
\text { shoreline }\end{array}$ \\
\hline $\begin{array}{l}\text { All shoreline } \\
\text { Coast (access via road }\end{array}$ & $700 \mathrm{~km}$ & $500 \mathrm{~km}$ & $71 \%$ \\
$\begin{array}{l}\text { possible) } \\
\begin{array}{l}\text { Archipelago (no road } \\
\text { connection) }\end{array}\end{array}$ & $290 \mathrm{~km}$ & $180 \mathrm{~km}$ & $62 \%$ \\
Lakes and rivers & $240 \mathrm{~km}$ & $160 \mathrm{~km}$ & $67 \%$ \\
\hline
\end{tabular}

The closeness to aquatic environments does not necessarily mean that the water areas are available for use. If the shoreline is built or in a private or otherwise restricted-use area, there is no access to the water area, which causes problems in terms of distributive environmental justice. Therefore, we define free shoreline as publicly accessible. Accessibility as a more extensive concept includes other aspects, such as the ability to reach the shoreline easily (e.g. existence of trails, availability of public transport and people's personal capacities and abilities). Water bodies themselves are generally free for nonmotorized recreational purposes in Finland. In general, a significant proportion of the water areas in Helsinki are free (Table 1).

Activities related to these aquatic environments are either directly provided by them (e.g. swimming, fishing and enjoying the lake landscape) or supported by them (e.g. sun bathing and walking along the shore) (Kakoyannis and Stankey 2002). In determining the accessibility of an amenity and related potential inequalities, the requirements of individuals and groups and their capacities to access and participate must be recognized.

We studied the actual use and accessibility of aquatic environments in the HMA with a Public Participatory Geographical Information System (PPGIS) approach (see a detailed description of methods in Brown and Kyttä 2014). A randomly sampled group of 
respondents used an online interface to mark different locations of aquatic environments they use and places they perceive as inaccessible on a map (Figure 3).
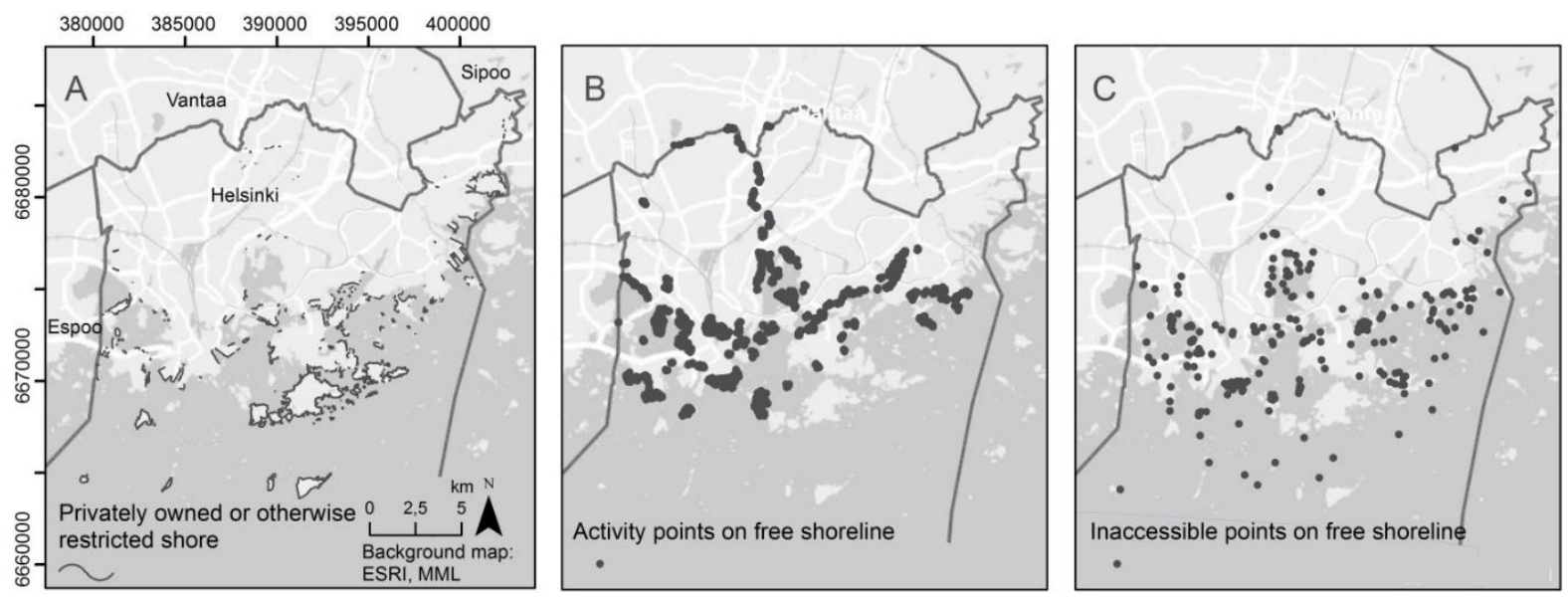

Figure 3. Analysis of free and restricted shoreline and PPGIS markers: (a) privately owned or otherwise restricted shoreline in the city of Helsinki, (b) most popular places located on free shoreline and (c) places perceived as inaccessible on free shoreline.

Altogether, 8763 activity points were marked on the maps; those points that were located in the sea or in the outer archipelago and accessible only by private boat were excluded from the analysis, producing a data set of 7360 points. Based on a cluster analysis, a cluster data set of 123 of the most popular areas by the water was observed (see more details in Laatikainen et al. 2017). The clusters and the 4695 activity points falling inside them represent the most popular areas by the water in the HMA. Of these total amounts, 82 clusters (67\%) and 3599 points (77\%) are located within the capital city of Helsinki. Furthermore, respondents marked a total of 541 places by the water in the HMA that they perceived as inaccessible, and of those, 359 were located in Helsinki.

The most popular places by the water were spatially analysed in terms of free shoreline within Helsinki. An overwhelming majority of $99.8 \%$ of the respondents' activity points are located on the free shoreline, and only five points are in areas that are privately owned or otherwise restricted (Table 2). The comparison of the free shoreline and activity point maps further confirms that the free shores of Helsinki are well used across the city, excluding the northeast corner, which is rather inaccessible without a private car. On the other hand, however, as much as $76 \%$ of the points that the respondents perceived as 
inaccessible were located next to a free shoreline where, in theory, everyone has free access. Many of these are located on islands that are rather close to the mainland but have limited access in terms of public transportation and ferry connections. Of the points, $24 \%$ were in private or otherwise restricted areas; most of the points were on two restricted military islands - Santahamina and Vallisaari - that were closed to the public at the time of the study (2014).

Table 2. Distribution of activity locations related to aquatic environments in Helsinki based on respondents' point markers in the PPGIS survey.

\begin{tabular}{lcccc}
\hline & \multicolumn{2}{c}{ Locations reflecting } \\
& $\begin{array}{l}\text { Larious types of activities } \\
(\mathrm{N})\end{array}$ & $\%$ & $\begin{array}{c}\text { Locations perceived } \\
\text { inaccessible }\end{array}$ & $\%$ \\
$\begin{array}{l}\text { Markers located on free } \\
\text { shoreline }\end{array}$ & 3594 & 99.8 & 272 & 76 \\
$\begin{array}{l}\text { Markers located on } \\
\text { private or } \\
\text { otherwise restricted }\end{array}$ & 5 & 0.2 & 87 & 24 \\
$\begin{array}{l}\text { shoreline } \\
\text { Total }\end{array}$ & & & & \\
\hline
\end{tabular}

It is interesting and important that some assignments of inaccessibility were recorded in shoreline areas that de facto were free. The reasoning behind perceived inaccessibility is presented in Table 3 . The notions primarily reflect personal perceptions and interpretations regarding the accessibility of places.

Table 3. Perceived inaccessibility of Helsinki shoreline according to the respondents of the PPGIS survey.

\begin{tabular}{lcc}
\hline \multicolumn{1}{c}{ Reason } & Count & \% \\
\hline Difficult to access by bike or on foot & 97 & 27 \\
Lack of public transportation & 95 & 27 \\
Restrictions in use & 46 & 13 \\
Lack of parking space & 41 & 11 \\
Physical barriers & 16 & 4 \\
Expensive transportation in HMA & 12 & 3 \\
Lack of access for physically disabled & 12 & 3 \\
people & & \\
Other reason & 38 & 11 \\
\hline Total & 357 & 100 \\
\hline
\end{tabular}


In order to gain a deeper understanding about the specificities of use and access to amenities, selected case studies were conducted in the project. Lake Kuusijärvi stands out as a land-locked water body with high recreational use and pressure.

For whom do the water areas in the HMA provide recreational services, and by whom are they used year round? A case study in the Lake Kuusijärvi area revealed strong seasonal changes in visitors' socio-demographic characteristics. A far more diverse group of people visited the lake area in the summer than in the off-summer season (Yli-Pelkonen and Vierikko 2016) when visitors formed a more homogenous group in terms of sociodemographic factors such as educational level, family type, age and type of living. Young adults ( $<30$ years), singles and families visited the lake area more frequently in the summer. Summer visitors tended to live more often in a rented apartment and did not own a vacation home as often as the off-summer visitors, indicating that the lake area is an important visiting place for these people to spend time with their family during the summer season. In addition, fewer summer visitors owned a car (see also Laatikainen et al. 2015).

Changes in water quality (e.g. blue-green algae blooms) or access to water areas can have a significant impact on outdoor recreation behaviour. The extent of substitution (i.e. whether a person can substitute swimming for another activity or go swimming elsewhere) can vary substantially. For the majority of visitors at Lake Kuusijärvi, it seemed to be difficult to find a substitute recreational water area. This may result from various factors, such as restricted or difficult access to some water areas or not owning a car to reach the alternative swimming sites (Laatikainen et al. 2015). In addition, a weak substitution capacity can either indicate strong place dependence or attachment to Lake Kuusijärvi (Raymond et al. 2010).

Possibilities and limits of substitution are linked to environmental justice concerns, such as the quality of the outdoor experience, the quality of the aquatic environments and the trade-offs and synergies between the use, production and maintenance of certain ecosystem services simultaneously. Some ways to engage with the water are not as readily substituted for than others, depending on the properties of the place (such as its complexity and richness in engagement opportunities), the aspirations of the visitors and their conditions (socio-economic, physical and otherwise) and on enabling factors in terms of technology, transport and other physical features as well as governance. For instance, children who remarkably benefit from nature activities, have fewer substituting options. 
Governance of water areas for environmental justice thus evidently requires attention to and practices accounting for the quality and specific conditions of the blue infrastructures, the conditions and particular needs of user groups and enabling factors such as access.

\section{Environmental justice in local-scale planning and governance of} aquatic environments

Is environmental justice ensured, and how, in governing and planning of the aquatic (and attached terrestrial) environments and managing them? In answering the question, the perspectives and methods that the city planners and other officials employed are important. These methods encompass planning and the implementation of plans, including policy and decision-making, funding and follow-up methods, and they involve participatory processes in which stakeholders and citizens interact and collaborate with officials.

In practice several challenges related to environmental justice may occur during the local land-use planning process. City officials working with the use and management of the green and blue infrastructure and with land-use planning in the HMA displayed contradictions between the planning ideals, the meanings the officials gave for the concept of justice, and the practices for the planning and management.

The interviewed officials understood justice as a procedural concept and emphasized justice as a founding principle for their work. It was highlighted in the interviews that a duty of officials is to ensure the 'greatest common good'. The concept of common good reflects the tradition of universalism, which has its roots in the Finnish welfare state system relying on universal rights and public benefits (Anttonen et al. 2012). Specifically, regarding recreational use of environment the so-called everyman's right has been commonly acknowledged in Finland as in other Nordic countries. However, the concept of common good, or public interest, is problematic. For example, the value of public interest as a legitimizing concept has increasingly been questioned because either those who make policies or those who evaluate them cannot reasonably operationalize them (Campbell and Marshall 2002). Moreover, in the context of ecosystem services, common good is a somewhat ambiguous concept and principle, as it involves, for example, trade-offs between different ecosystem services and public services as well as conflicting interests between 
specially favoured or disfavoured groups (i.e. the extent that a particular group's needs should be accountable in the common good) (Vierikko and Niemelä 2016).

Moreover, what is challenging with the common good concept is the notion that it is often understood very differently by various actors involved in the planning and decision-making procedures, such as the land-use planners and political decision makers, as well as by local residents (Vierikko and Niemelä 2016). This finding emphasizes the need to consider and pay attention to these varying perspectives in the planning and decision-making processes. Very different perspectives and preferences also are commonly seen with regard to the distribution of environmental (and other) burdens and benefits between generations.

From the procedural justice point of view, ensuring common good is not enough for ensuring justice if it is unclear whose needs are recognized and taken into account in the process (cf., Schlosberg 2007). Differentiating between users of environmental amenities challenges preconceived and monolithic 'public interest' justifications in planning by drawing attention to particular ecosystem services and their diverse users. This is especially important in the cities having high infill development such as Helsinki where the construction of residential areas is usually achieved to the detriment of green or blue-green areas (Kabisch and Haase, 2013, Haaland and van den Bosch, 2015). The emphasis on environmental justice and ecosystem services requires that the perspective of various user groups, such as children, adolescents, immigrants and the future generations who benefit vicinity urban green and blue areas, are included in urban planning. This creates challenges to be considered in the planning process in densified cities: From the perspective of recognition, it is relevant to investigate whether or not various current and future stakeholder groups have an equal voice over the ecosystem services; who determines to whom the voice is given; in what kind of processes this happens; how the concerns of different interest groups are noted (or represented) in the processes of governing on ecosystem services; and how capabilities of various groups to participate are approached and ensured.

According to the interviews of the city officials, several participatory tools, including citizen events in different residential areas, organized city plan walks, hearings, internet questionnaires, interviews, negotiations and initiatives are increasingly used in the HMA (Lehtomäki and Paloniemi 2016). Hearings and citizen events still dominate, which is contradictory to the previous notion that the planners perceive them as non-effective and poorly functional (see Puustinen 2006, 303). 
These experiences from local land-use contexts illustrate strengths or opportunities as well as weaknesses or limitations of planning in addressing environmental justice issues also in the use of aquatic environments. Some of these strengths and limitations gain particular characteristics in the case of water areas (e.g., a less-pronounced construction pressure, or other differences due to physical, ecological, social, or legal reasons), while others are generic. Being grounded on existing statutes and local procedures, they also inform the implementation of newer and higher-level planning instruments such as MPs and RBMPs.

\section{Conclusions of challenges and opportunities in environmental justice}

Both distributive and procedural aspects are relevant in developing environmental justice of planning and decision-making processes. In this paper, by focusing on the governance of aquatic environments and related ecosystem services in the HMA, we found three main challenges related to how multi-level and multi-actor governance, especially participatory planning and decision-making processes, could be improved from the perspective of environmental justice.

First, our results showed that most of the shoreline of Helsinki is free and/or accessible, and accordingly, the shoreline has been very actively used by people for recreational purposes. Most of the activities take place in the free shorelines, but people also noted a remarkable amount of inaccessible points along waterbodies, many of these being in the archipelago. Many of the points perceived as inaccessible were actually located by the free shoreline, reflecting a need to combine factual and perceived accessibility of ecosystem services in detail during the planning processes, and to discuss reasons for possible discrepancies between the two.

Second, we found that many residents can have a restricted possibility to find an alternative recreational water area. These findings related to low substitution capacity indicate a need to pay more attention to social-demographic factors explaining the distribution of the use of public areas and the ecosystem services they deliver. For example, vulnerability of specific social-demographic groups to potentially decreasing ecosystem services of a particularly important public space is of concern.

Third, we found that despite the diversified involving methods, local planners seem to have difficulties capturing the variety of perceptions of local people and integrating 
various actors and their perceptions into planning and decision-making processes. This challenge is likely even more remarkable in multi-level and multi-sector planning and governance frameworks. From the point of view of improving environmental justice, the emerging planning and governance instruments on higher spatial scales, such as MSPs and RBMPs, need to be aware of local procedures and processes and thereby adjusted to local conditions. In addition, there are significant opportunities in improved interaction and coordination between various levels and sectors of governance and, importantly, in involving citizens and civil society organizations and groups in participatory approaches, if done in a manner that is well-conceived, based on sufficient resources including knowledge or facilitation and genuinely aiming at social innovation in multi-actor governance. A key opportunity is to resolve conflicting values even before they arise or have jammed the system (i.e. one of consensus- and cohesion-building). In this process of integration, the existing and new planning systems will interact, and both will be modified. In this regard, concerns regarding environmental justice and the possibilities of citizens to participate in a deliberative governance process are crucial.

Building on these observations, we believe that research on environmental justice can improve the practices of aquatic environmental governance. In this setting, it is important to recognize governance barriers that can prevent end-users' preferences and information reaching planners. Such information is crucial as decisions are made under several legislative frameworks, over several timescales, by several different authorities and on several spatial scales (national, regional and local). Consequently, the planning of aquatic environments runs a risk of detaching itself from actual user preferences if interactions between planning systems and knowledge accumulated in different planning processes are not communicated, and thoroughly considered. Thus, the perspectives of distributive and procedural environmental justice should be better incorporated into planning and decisionmaking processes to overcome unwanted trade-offs and potential conflicts in the use and management of aquatic environments.

\section{Acknowledgements:}

We would like to thank Julian Agyeman, Áslaug Ásgeirsdóttir, Hermanni Backer, Christopher Boone, Daud Hassan, Christopher Raymond, Pekka Itkonen, Ekaterina Khmeleva, Riina Toivanen, Tiina Tihlman, Daniela Hellgren, Jenni Kuoppa and Marko 
Järvinen for participating in the theory and method development during the ENJUSTESS research project. Special thanks for Mary Lukkonen for editing language and valuable comments improving the manuscript.

\section{Funding:}

This work was funded by the Academy of Finland as a part of the Academy Programme “Sustainable Governance of Aquatic Resources (AKVA)” [grant number 263403].

\section{References}

Agyeman J. 2005. Sustainable communities and the challenge of environmental justice. New York University Press: New York and London.

Agyeman J., Bullard R.D., Evens B., eds. 2003. Just Sustainabilities: Development in an Unequal World. The MIT Press: Cambridge and Massachusetts.

Anttonen, A., Häikiö L., Stefansson, K., eds. 2012. Welfare State, Universalism and Diversity. Edward Elgar, Cheltenhamn, 202 pages.

Boone, C.G., Buckley, L.G., Grove, J.M., Sister, C. 2009. Parks and People: An Environmental Justice Inquiry in Baltimore, Maryland. Annals of the Association of American Geographers 99(4): 767-787.

Brown, G. \& Kyttä M. 2014. Key issues and research priorities for public participation GIS (PPGIS): A synthesis based on empirical research. Applied Geography 46, 122-136

Campbell, H., \& Marshall, R. 2002. Utilitarianism's Bad Breath? A Re-Evaluation of the Public Interest Justification for Planning. Planning Theory, 1(2), 163-187.

Chaix B., Gustafsson S., Jerrett M., Kristersson H., Lithman T., Boalt Å., Merlo J. 2006. Children's exposure to nitrogen dioxide in Sweden: investigating environmental injustice in an egalitarian country. J Epidemiol Community Health 60:234-241.

Davos C.A. (1986) Group Environmental Preference Aggregation - The Principle of Environmental Justice. J Environ Manage 22 (2): 55-65.

Ernstson, H. 2013. The social production of ecosystem services: A framework for studying environmental justice and ecological complexity in urbanized landscapes. Landscape and Urban Planning 109(1): 7-17.

Finnish Environment Institute 2016. Shoreline 10 (Ranta10) and river networks. Information available: 


\section{HTTP://GEOPORTAL.YMPARISTO.FI/META/JULKINEN/DOKUMENTIT/SHORELINE 10_RIVERNETWORK.PDF}

Giller, K. E., C. Leeuwis, J. A. Andersson, W. Andriesse, A. Brouwer, P. Frost, P. Hebinck, I. Heitkönig, M. K. van Ittersum, N. Koning, R. Ruben, M. Slingerland, H. Udo, T.

Veldkamp, C. van de Vijver, M. T. van Wijk, and P. Windmeijer. 2008. Competing claims on natural resources: what role for science? Ecology and Society 13(2): 34.

http://www.ecologyandsociety.org/vol13/iss2/art34/?

Granit, J., Lymer, B.L., Olsen, S., Lundqvist, J., Lindström, A. 2014. Water Governance and Management Challenges in the Continuum From Land to the Coastal Sea-Spatial Planning as a Management Tool. SIWI Paper 22.

Hester, R.T. (1987) Participatory Design and Environmental Justice - Pas-De-Deux or Time to Change Partners. J Architectural and Planning Res 4 (4): 289-300.

Kabisch, N., Haase, D. 2013. Green spaces of European cities revisited for 1990-2006. Landscape and Urban Planning, 110, 113-122.

Haaland, C., Van den Bosch, C. K. 2015. Challenges and strategies for urban green-space planning in cities undergoing densification: A review. Urban Forestry \& Urban Greening, $14,760-771$.

Kabisch, N., Dagmar, H. 2014. Green justice or just green? Provision of urban green spaces in Berlin, Germany. Landscape and Urban Planning 122, 129-139

Kakoyannis, C., Stankey, G. 2002. Assessing and evaluating recreational uses of water resources: Implications for and integrated management framework. General Technical Report, Forest Service, United States Department of Agriculture. pp. 59

Laakkonen, S: 2001: Vesiensuojelun synty. Gaudeamus, Helsinki. 309 p. [in Finnish]

Laine M., Peltonen L. 2003. Ympäristökysymys ja aseveliakseli. Ympäristön politisoituminen Tampereella vuosina 1959-1995. Tampereen yliopistopaino Oy - Juvenes Print, Tampere. 511 p. [in Finnish]

Laatikainen T., Tenkanen H., Kyttä M., Toivonen T. 2015. Comparing conventional and PPGIS approaches in measuring equality of access to urban aquatic environments. Landscape and Urban Planning 144: 22-33.

Laatikainen, T., Piiroinen, R., Lehtinen, E., Kyttä, M. 2017. PPGIS approach for defining multimodal travel thresholds: Accessibility of popular recreation environments by the water. Applied Geography 79: 93-102. 
Lehtomäki E., Paloniemi R. 2016 Kansalaisten osallistuminen ja kestävä hyvinvointi. Janus 24(4): 320-339.

Millennium Ecosystem Assessment (2005) Ecosystems and human well-being: synthesis. Washington, DC: Island Press.

Paloniemi R., Apostolopoulou E., Cent J., Bormpoudakis D., Scott A., Grodzinska-Jurczak M., Tzanopoulos J., Koivulehto M., Pietrzyk-Kaszynska A., Pantis J. D. 2015. Public participation and environmental justice in biodiversity governance in Finland, Greece, Poland and the UK. Environment Policy and Governance 25(5): 330-342

Pietilä, M., Neuvonen, M., Borodulin, K., Korpela, K., Sievänen, T., Tyrväinen, L. 2015. Relationships between exposure to urban green spaces, physical activity and self-related health. Journal of Outdoor Recreation and Tourism 10, 44-54.

Puustinen, S. 2006. Suomalainen kaavoittajaprofessio ja suunnittelun kommunikatiivinen käänne. Vuorovaikutukseen liittyvät ongelmat ja mahdollisuudet suurten kaupunkien kaavoittajien näkökulmasta. Yhdyskuntasuunnittelun tutkimus- ja koulutuskeskuksen julkaisuja A34, Espoo, 354 p. [in Finnish]

Raymond, R.M., Brown, G., Weber, D. 2010. The measurement of place attachment: Personal, community, and environmental connections. Journal of Environmental Psychology $30,422-434$.

Schlosberg D. 2007. Defining Environmental Justice: Theories Movements and Nature. Oxford University Press: Oxford.

Sikor, T., Ed. 2013. The Justices and Injustices of Ecosystem Services. Milton Park, Earthscan.

Söderberg, C. 2016. Complex governance structures and incoherent policies: Implementing the EU water framework directive in Sweden, J Environ Mgmt. 183: 90-97.

Soininen, N. 2015. Marine spatial planning in the European Union. In Hassan, D., Kuokkanen, T. \& Soininen, N. eds. Transboundary Marine Spatial Planning and International Law, Earthscan Routledge, p. 189-201.

Staffans, A. 2004. Vaikuttavat asukkaat. Yhdyskuntasuunnittelun tutkimus- ja koulutuskeskuksen julkaisuja A 29, Espoo. 312 p. [in Finnish]

Tzoulas, K., Greening, K. 2011 Urban ecology and human health, in J. Niemelä, ed. Urban ecology - patterns, processes, and applications, 2011, Oxford. p. 263-271. 
Vaattovaara, M., Kortteinen, M. 2012. Segregaatiosta ja sen inhimillisestä ja yhteiskunnallisesta merkityksestä. Talous \& yhteiskunta, 40: 3, 60-66. [in Finnish]

Vierikko K., Niemelä J. 2016. Bottom-up thinking - Identifying socio-cultural values of ecosystem services in local blue-green infrastructure in Helsinki, Finland. Land Use Policy 50: $537-547$.

Vilkama, K. 2011. Yhteinen kaupunki, eriytyvät kaupunginosat? Kantaväestön ja maahanmuuttajataustastaisten asukkaiden alueellinen eriytyminen ja muuttoliike pääkaupunkiseudulla. Tutkimuksia 2011: 2. Helsingin kaupungin tietokeskus. [in Finnish with a synopsis in English]

Völker, S., Kistemann, T. 2011. The impact of blue space on human health and well-being Salutogenetic health effects of inland surface waters: A review. International Journal of Hygiene and Environmental Health 214 449-460. https://doi.org/10.1016/j.ijheh.2011.05.001

Yli-Pelkonen V., Vierikko K. 2016. Vantaan Kuusijärvi tarjoaa virkistyskokemuksia ympäri vuoden. Viherympäristö 5/2016: 12-13. [in Finnish] 